\title{
Assessing Farmers Risk Attitudes and Coping Strategies Among Apple Growers
}

\section{Emerging Evidence from Ahmad Aba, Paktia, Afghanistan -Risk Behaviors Model (RBM), and Regression Approach-}

\author{
By
}

Najeebullah AHMADZAI

Department of Agricultural Economics, Agriculture Faculty, Paktia University, Paktia, Afghanistan

DOI: 10.29322/IJSRP.10.07.2020.p10364

http://dx.doi.org/10.29322/IJSRP.10.07.2020.p10364

\begin{abstract}
Multidimensional exogenous and endogenous factors are introducing a high degree of uncertainty and inversely impacts farmers' income as well as the gross national product of the country. This study elucidates apple growers' risk attitudes and risk-smart options, in Ahmad Aba, Paktia. The study applies Risk Behavioral Model (RBM) and regression analysis using 85 samples among apple farming households, from January to February 2020. The study reveals that $76.47 \%$ of the farmers have been deprived of access to extension services, meanwhile the extension work are positive and significantly related to farmers' risk attitudes. Also, the result shows that $55.29 \%$ of the respondents are risk-averse; moreover, 44 and 20 percent of the respondents have experienced mild and sever risk, respectively. Besides, the result of regression analysis shows that production, age of the farming household head, education, gender, and off-farm income are significant in explaining farmers' risk attitudes in the selected area. The risk smart-arts chosen by farmers to mitigate the prevalence risk level include intercropping, off-farm employment, decrease in expenditures, participation in unions, post-harvest management, and financial/credit reserve strategies.
\end{abstract}

KEYwORDS: Risk Attitudes, Risk Determinant, Coping Strategies, Apples, Paktia, Afghanistan

\section{INTRODUCTION}

Apples are the major producing fruit in Afghanistan, providing subsistence food nutrients and generates employment opportunities to growers across the country. Given the favorable climate conditions throughout the county, apple growers abled and produced abundant amounts with greater improvement in the latest two decades. Nevertheless, in Afghanistan, most of the apple producers are small-scale farmers, with fewer opportunities for access to credit, extension workers, and membership in the business and social organizations. Besides, the lack of information on farmers' risk preferences has created ambiguity for researchers and policymakers in designing sophisticated risk management instruments (Lucas and Pabuayon, 2011; Ellis, 2000; Ayinde, 2008). Moreover, agricultural activities are affected by various types of risk, that includes production risk (such as risk associated with yield, climate risk, and epidemic diseases); the risk associated with currency exchange rates; price volatility risk; and risk of competition in the global markets (Ullah et al., 2016; Abay et al., 2009). Consequently, the empirical result of various studies shows that farmers attitudes toward risk influences most of their production and economic decisions; for instance, cropping patterns (Maynard, Harper, Hoffman, 1997), willingness to 
participate in crop insurance (Niewuwoudt and Bullock, 1985; Sulewski, Gajewska, 2014), and technology adoption (Chavas and Holt, 1996; Liu, 2013), which in large extent influences the success of many development programs in the rural areas (Adejoro, 2000; Tonye et al., 1977). Thereby, assessing farmers' attitudes toward risk are essential factors shaping farmers' decisions overall the uncertain circumstances (Akcaoz and Ozkan, 2005).

In the landlocked developing countries, agriculture and raising livestock are the backbone of the rural economy; hence, most of the farmers' decisions are driven by 'safety-first' rule; implying that farmers firstly ensure their future safety, then take an action toward a secured direction (Scandizzo and Dillon, 1976). Meanwhile, farmers' opportunities and challenges differ depending on their psychological make-up and the surrounding socio-economic circumstances. Moreover, factors affecting farmers' behavior and state of risk aversion taken by a particular group of farmers could be estimated from their observed behaviors (Moscardi and Javry, 1977). The state of risk aversion in most of the agricultural entrepreneurship can be estimated by pests and widespread diseases, weather-related problems, low yielding varieties, miss-management, and lack of technology and owner capital (Isiaka 1998; Apantaku et al., 1998; Famure, 1988; and Eekeren et al., 1995). Eventually, all these factors lead to a low level of the farm gross revenue; the study arrived by Pender, 2001 stating that the variation in productivity and deviation from the mean gross revenue can be minimized by proper handling of riskmanagement activities. In addition, the selection of appropriate coping strategies and risk-smart options are an alternative solution for the farmers to avoid or alleviate the dominant risk level. The risk coping options studied by Hardaker et al., 2004 include access to valid information sources, cooperative membership, employment of appropriate technologies, livelihood diversification, access to the credit and insurance services.

Despite the lack of knowledge that we have on the sources of risk and that why it occurs; perceiving individual risk attitudes are the main criterion to recognize their economic characteristics (Reynaud and Couture, 2012); moreover, understanding farmers' economic behaviors are the key factor in designing a responsible agricultural development strategy (Euphrasie B.H., et al; 2012).

In addition, in this study, we assess farmers' perceptions of various risk sources. In agriculture, sources of risk might be categorized into production, market, institutional, and financial risk sources (NIPC, 2006; Njavro, 2009; Dercon, 2002, and Mikhaylova, 2005). Given the high interdependence between input and output, market and production risks are highly correlated to each other. Therefore, fluctuation in input and output prices result in market risk. Furthermore, market risk can be the result of market cartel, an organization willing to control the market prices by excluding the small competitors from the market. Eventually, the uncertainty introduced by fluctuations in the market is hindered by production planning, which in turn leads to inefficient resource allocation (Ellis, 1998 and Ellis, 2000; Hazzel, 1998). Another source of risk in the study area is institutional risk; four decades of political instability across the country is the main cause of institutional risk. Institutional risk can be either political relating to the instability in governance and their policies, or sovereign risk occurs due to not commitment of foreign governments to the mutual agreements such as trade agreements (Hardaker et al., 2004) or transaction risk which is the results of opportunistic behavior and the reliability of transacting partners (Dorward et al.,2007).

Considering the previous studies, risk attitudes are significantly variant among the respondents (Flaten et al. 2005) because of heterogeneity in the age (Ashraf and Routray 2013; Kammar and Bhagat 2009; Iqbal et al. 2016; Kisaka-Lwayo and Obi 2012), respondents' education level (Dadzie and Acquah 2012; Khan et al 2010), income (Einav et al 2010), experience in farming (Lucas and Pabuayon 2011), income obtained from nonfarm sources (Ullah et al. 2015), and farm size (Iqbal et al. 2016; Lucas and Pabuayon 2011). This study aims to investigate farmers' risk attitudes, risk determinants, farmers' perception about risk sources, and coping strategies among apple farmers in Ahmad Aba, Paktia, Afghanistan. 


\section{MethodS AND ANALYTICAL TECHNIQUeS}

\subsection{STUDY SITE AND DATA COLLECTION}

This study is conducted in the southeast of the country focusing on four villages in the Ahmad Aba district. The study area is chosen because of its proper soil, socioeconomic, and suitable climatic condition for apples growing. Moreover, the study is conducted in a rural area where the majority of the residents are living on small-scale farming and raising livestock. The data used in this study have been collected through face-toface interviews using a structured questionnaire. For the purpose, 85 apples farming households were randomly selected and interviewed for their risk preferences, socio-economic conditions, risk perception, and coping-strategies for effective risk management in the study area.

\subsection{ANALYTICAL TECHNiQUeS}

Descriptive statistics have been used to summarize the main characteristics of respondents in terms of frequencies and percentages, purposively. Furthermore, farmers' risk preferences were analyzed using the Risk Behavioral Model (RBM). The model is driven by safety-first rule, ensuring the minimization of the probability of suffering from the shortfall in income lower than a certain critical level. The specific model developed by Roy (1952), followed by Sekar and Ramasamy (2001) and Salimonu and Falusi (2007), is given as follows:

$$
\Psi \mathrm{i}=(\partial \mathrm{i}-\mu \mathrm{i}) / \sigma \mathrm{r}
$$

Where, $\Psi \mathrm{i}$ shows the risk aversion index, represents respondent monthly returns disaster level indicates farm expected return, and stands for the standard deviation of the household income. It is worth noticing that, the income disaster level $(\partial \mathrm{i})$ is the amount of income in which the farm household is compiled to borrowing or selling-off farm-related assets to alleviate the extreme poverty level. Moreover, the socio-economic circumstances with a decision-maker could determine the income disaster level (Sekar and Ramasamy, 2001). The individual farmer toward his behavior is risk-averse if, $\Psi_{\mathrm{i}}<0$, the respective respondent is risk neutral in case of $\Psi \mathrm{i}=0$; lastly, the respondent is risk seeker if $\Psi \mathrm{i}>0$.
In this study, the socioeconomic factors affecting farmers' risk attitudes is determined using ordinary least square multiple regression model, empirical structure of the model is specified as bellow:

$$
\begin{aligned}
& Y=\beta_{0}+\beta_{1} X_{1}+\beta_{2} X_{2}+\beta_{3} X_{3}+\beta_{4} X_{4}+\beta_{5} X_{5}+\beta_{6} X_{6} \\
& +\beta_{7} X_{7}+\beta_{8} X_{8}+\beta_{9} X_{9}+\beta_{10} X_{10}+\varepsilon
\end{aligned}
$$

Where; Y represents farmer risk aversion Index (as indicated in equation 1$), X_{j}(j=1,2, \ldots, n)$ is the vector of predictor variables used in the analysis (including socioeconomic characteristics of farmers and their orchards related variables, that consist apples production, garden size, age of the household head, education level, experience in farming, cooperatives membership, gender, marital status, experience with risk, household size, access to credit, and access to extension work). $\beta_{\mathrm{ij}}$ is the vector of unknown parameters to be estimated $(\mathrm{i}=1,2, \ldots, \mathrm{p} ; \mathrm{j}=$ $1,2, \ldots, \mathrm{n})$; and $\varepsilon$ is indicating the random noise term.

Multinomial logit model is employed to analyze the effects of socioeconomic characteristics on the selection choice of farmers' risk coping strategies. The risk copping options used in the multinomial logit model against the socioeconomic characteristics of farmers include intercropping, off-farm employment, decreasing in expenditures, membership in unions (production/ business), post-harvest management, financial/credit reserve, and no risk strategy. In the study model, no risk strategy is normalized and used as a "reference or base" category. Besides, Hausman-test is employed to assess the reliability and validity of the model used for the analysis, purposively. Subsequently, the result indicated that the multinomial logit model is applicable to risk-coping strategies affected by the dominant socioeconomic factors. Hence, a multinomial logit model is employed to analyze the existing relationship between a polytomous explained variable and a set of explanatory variables (Onubuogu and Esiobu, 2014). The structured form of the modal is as follows;

$$
\begin{aligned}
& \operatorname{Pr}(Y i=j)=e \beta j x i j, \quad j=0,1,2,3, \ldots, 6 \\
& 1+\Sigma e^{\beta m x i j} \\
& P j=\operatorname{Pr}(Y i=j)=e \beta j x i j, \quad j=0,1,2,3, \ldots, 6 \\
& 1+\Sigma e^{\beta m x i j} m=0
\end{aligned}
$$


Here, $\operatorname{Pr}(\mathrm{Yi}=\mathrm{ji})$ represents the probability of preferring any of the risk coping-strategies; and $\mathrm{j}$ is the number of risk-coping strategies in the choice set of options, $\mathrm{X}_{\mathrm{i}}$ indicates vector of explanatory socio-economic variables, $\beta \mathrm{j}$ is vector of the estimated parameters. The probability response is represented as bellow.

Where, $\mathrm{P}$ is indicating response probability

$$
(\mathrm{J}=0,1,2,3, \ldots \ldots, 6)
$$

$\mathrm{Y}$ is showing risk coping category; where $\mathrm{j}=1,2,3,4,5,6$ (in our study that includes intercropping, off-farm employment, decreasing in expenditures, membership in unions (production/ business), post-harvest management, and financial/credit reserve strategy).

\section{STUDY RESULT}

\subsection{DESCRIPTIVE RESULT}

Table 1 reported the respondents' characteristics by looking at the frequency and percentage. Result revealed that the majority of farmers in the area are between 20 to 40 years old (52\%), pointing out that they are still younger and can obtain the technical skills and adopt new technology and innovations. It is also observed that most of the farming household heads are uneducated (40\%, indicated in the table 1). On the other hand, farmers' education is directly related to their contribution toward development programs, awareness, and adoption of innovations, and it could enhance their risk management skills (Fawole and Fasina, 2005). Moreover, $44.7 \%$ and $20 \%$ of the farming households have experienced mild and sever risk, respectively. It is also observed that the majority of farming households are having more than 8 persons as a family; moreover, the empirical results of various studies (Gebremedhin and Scott 2003; Babalola and Babalola, 2013) have found that household size is directly related to the expected expenditures. On the contrary side, family young members contribute to the farm as a labor (Peter and Susan, 2014), hence a bigger size of households provides adequate labor leading to a decrease in the farm labor cost. The data describes that most of the farmers have no access to extension services $(76.47 \%)$; (Chikaire et al., 2011) have found that farmers' access to the extension can enhance their access to technology learning and improved production inputs for being effective in risk management and efficiency in farm production. Implying, that the fruit producers deprived of access to extension workers are more vulnerable for being more risk-averse. Also, the descriptive result revealed that majority of the farmers have no access to formal credit services $(82.35 \%)$, the empirical results of various studies have shown that imperfect credit markets result in influencing farmers' demand for agricultural inputs and crop insurance (e.g., Binswanger-Mkhize, 2012; Giné et al., 2008; Karlan et al., 2014; Farrin and Miranda, 2013).

Table 1: Distribution of farmers' characteristics

\begin{tabular}{|c|c|c|}
\hline Characteristics & $\begin{array}{l}\text { Frequency } \\
\quad(n=85)\end{array}$ & $\begin{array}{c}\text { Percentage } \\
(\%)\end{array}$ \\
\hline \multicolumn{3}{|l|}{ Age } \\
\hline$<20$ & 6 & 7.06 \\
\hline $20-40$ & 45 & 52.94 \\
\hline$>40$ & 34 & 40 \\
\hline \multicolumn{3}{|l|}{ Education } \\
\hline None & 35 & 41.18 \\
\hline Primary & 28 & 32.94 \\
\hline Secondary & 20 & 23.53 \\
\hline Tertiary & 2 & 2.35 \\
\hline \multicolumn{3}{|c|}{ Experience in farming } \\
\hline Less than 5 years & 22 & 25.88 \\
\hline Between 11 to 15 & 45 & 52.94 \\
\hline More than 15 & 18 & 21.18 \\
\hline \multicolumn{3}{|c|}{ Membership in a cooperative } \\
\hline No & 49 & 57.65 \\
\hline Yes & 36 & 42.35 \\
\hline \multicolumn{3}{|c|}{ Access to extension services } \\
\hline No & 65 & 76.47 \\
\hline Yes & 20 & 23.53 \\
\hline \multicolumn{3}{|l|}{ Gender } \\
\hline Female & 4 & 4.71 \\
\hline Male & 81 & 95.29 \\
\hline \multicolumn{3}{|l|}{ Marital status } \\
\hline Single & 12 & 14.12 \\
\hline Marriage & 73 & 85.88 \\
\hline \multicolumn{3}{|l|}{ Experience with risk } \\
\hline None & 30 & 35.29 \\
\hline Mild & 38 & 44.71 \\
\hline Sever & 17 & 20 \\
\hline \multicolumn{3}{|l|}{ House hold size } \\
\hline Equal to 8 or less & 22 & 25.88 \\
\hline More than 8 person & 63 & 74.12 \\
\hline \multicolumn{3}{|l|}{ Access to credit } \\
\hline No & 70 & 82.35 \\
\hline Yes & 15 & 17.65 \\
\hline Total & 85 & 100 \\
\hline
\end{tabular}

Source: Field survey data, 2020 


\subsection{RESULT AND DISCUSSION}

This study was employed to provide the baseline information regarding farmers' attitudes toward risk and uncertainty in apple production. Table 4 shows the summary statistics for the risk version levels in the risk behavioral model. The findings show that $55.29 \%$ of the respondents are riskaverse. Indeed, the result reaffirms the generally accepted statement that most of the farmers are risk-averse in their daily decisions; also, the result is consistent with that of the empirical results of various studies (Adubi, and Ramasamy, 2001;

Shahabuddin et al 1986). Furthermore, the risk-averse attitude of farmers reveals that they are not willing to utilize any opportunity associated with any kind of risk and uncertainty. Moreover, the remained $27.06 \%$ of respondents are risk prefer, and less proportion of the respondents are found to be riskneutral $(17.65 \%)$.

Table 2: Status of the respondents by risk preferences

\begin{tabular}{cccc}
\hline Category & $\begin{array}{c}\text { Risk aversion } \\
\text { index }\end{array}$ & $\begin{array}{c}\text { Frequency } \\
(\mathbf{n = 8 5})\end{array}$ & $\begin{array}{c}\text { Percentage } \\
(\mathbf{\%})\end{array}$ \\
\hline Risk averse & $<1$ & 47 & 55.29 \\
$\begin{array}{c}\text { Risk } \\
\text { indifferent } \\
\text { Risk } \\
\text { preferring }\end{array}$ & 1 & 15 & 17.65 \\
\hline
\end{tabular}

Source: Computed from field survey, 2020

Estimates for regressing the socioeconomic variables one farmers' risk attitudes are reported in table 5. The R2 value exhibited that $64 \%$ of the variation in farmer risk attitudes was explained with the explanatory variables given in the study model for the analysis purpose. The rest of the variation is due to the independent variables which are not included in the study model, known as the error term. Also, the F-statistic is significant at the alpha level of $1 \%$, implying that all of the explanatory variables have a joint impact on the explained variable. The socioeconomic variables that include apple production, farm household head age, education level, farming experience, gender, experience with risk, off-farm income, and extension work are found to be significant in explaining farmers' risk attitudes. According to the result, the age of the household head is varying inversely with the attitudes toward risk, indicating that the higher the age of the farmer, the less risk-averse he/she will be. Indeed, older farmers are well acquainted with risk; hence they have accumulated more wealth and it can assist them to combat risk and lessen the negative effects of risk on their expected output (Aye and Oji, 2007). Also, older farmers are more likely to have a strong social profile and social incentives that contribute them to develop a risk-prefer plan of action; the finding is consistent with that of Ullah et al. (2015), Dadzie and Acquah (2012), and Iqbal et al. (2016).

Although the coefficient sign of orchard size is positive, it is found to be insignificant revealing that not likely to influence farmers' attitudes toward risk. The finding is contradictory with the study result of Foster and Rauser (1991), stating that the proportion of the cultivated area is inversely related to the farmer risk attitudes. The logic behind our result is the sufficient income generation for fulfilling farmer subsistence requirements; thus the marginal effects of income received from a cultivated area gradually decrease as income rises beyond the subsistence requirements of a farming household (Ayinde, 2008). The result showed that education is significant and varying inversely with farmers' attitude toward risk, indicating that the higher the education level, the lower risk-averse is the farmer; furthermore, access to technical information on various sources of risk is directly attributed to the education level of farmers; hence an educated farmer can choose from a choice group strategies ensuring a confident return to the farm, the finding is consistent with the study result of Yesuf (2007). The coefficient of experience in farming is positive and significantly influencing farmers' risk attitudes, enlightening that apple growers with more experience are found to be more risk-averse compared to that of having less experience along with apple production. The study result is contradictory with the finding of Ayinde (2008) revealing that experience in farming is inversely related to the risk aversion behaviors of farmers. Furthermore, the dummy variable of gender is consistent with the prior sign expectation, a positive and significant relationship was found between gender and farmers' risk attitudes, implying that male farmers are more risk-prefer in comparison to their female counterpart, in line with the empirical findings of various studies such as Weber, Blais, and Betz 2002; Harris, Jenkins, and Glaser 2006; Byrnes, Miller, and Schafer 1999. 
Off-farm income as a scale variable of the study had a positive and statistically significant impact on farmer risk preferences. Meaning that low off-farm decision-makers are more risk-averse compared to the higher off-farm income farmer. Furthermore, farmer with higher off-farm income has stronger risk bearing capability and less vulnerable from the negative effects of risk; consistent with the findings of Iqbal et al. (2016), and Lamb (2003), stating that the off-farm income and risk aversion coefficient is trading-off to each other, low off-farm income is associated with the higher risk aversion and vice versa. Access to extension services was inversely related to farmers' risk attitudes; in line with the study findings of (Ayinde, O. E., 2008) revealing that the technical benefit from the extension work can increase the willingness of the farmer to take a further risk; and (Arce, 2010) it has a policy implication, that further extension contacts ought to be conducted to enhance farmers' behaviors and potential for effective risk management.

Table 3: Impact of socioeconomic determinants on farmers' risk attitudes

\begin{tabular}{lll}
\hline Variable & Coefficient & t-value \\
\hline Constant & 9.231 & $-6.325^{*}$ \\
Production & 0.452 & $3.047 * *$ \\
Garden size & 0.046 & 0.487 \\
Age & 0.234 & $2.341 * *$ \\
Education level & 0.074 & $-3.403 * *$ \\
Experience (year) & 0.212 & $2.480 * *$ \\
Membership in Coop. & 0.087 & 1.265 \\
Gender & 0.402 & $3.450 * *$ \\
Marital status & 0.205 & 0.030 \\
Experience with risk & 0.034 & $5.431 *$ \\
Household Size & 0.182 & 1.583 \\
Off-farm income & 0.342 & $2.378 * *$ \\
Access to Credit & 0.451 & 0.673 \\
Extension Agent & 1.345 & $-2.507 * *$ \\
\hline
\end{tabular}

Source: computed based on field survey (2020)

$* * *$ Significant at $1 \%, * *$ Significant at $5, *$ Significant at $10 ; \%, \mathrm{R}^{2}=0.643, \mathrm{~F}$ - value $=32.825$

Despite risk is a widespread and unavoidable phenomenon in every business, it is distinctive in farming, mainly arising due to the unwanted weather conditions, the density of pests and diseases, production seasonality, production geographical dispersion, changing consumer behaviors (Ullah et al. 2015; McNeil et al. 2015), natural catastrophes (World Bank 2011), fluctuation in yields and their prices (Musser and Patrick 2002), and lack of financial facilities along with risk management strategies such as credit and insurance (Jain and Parshad 2006; Musser and Patrick 2002).

Figure 1 documented various sources of risk and farmers' perception, in the study area. In this study, marketing, financial, political, environmental, and social uncertainties are considered as the main sources of risk that affect farmers' daily decisions. It is worth noticing that, the term marketing used in this study involves the whole channel of apples possessing from the orchard to the final consumer, which includes transportation, storage, processing, selling and post-harvest management. Risk associate with marketing risk is perceived as highest and intensive by the respondents compared to the other sources of risk in the study area. Similar to the other landlocked developing countries, high transportation and marketing costs have isolated farmers from national and international markets across the country. Furthermore, the production and market risks are highly correlated to each other, and the degree of correlation is depending on the integrity of regional markets (Sadoulet and De Janvry, 1995). Moreover, market volatility introduces uncertainty into farm planning which makes it difficult to define the future pathway confidently; in the case, inefficient resource allocation can be expected (Ellis, 1998; Hazzel, 1998; and Ellis, 2000). Risk management instruments are documented by (Hartwich and Gandorfer, 2014) revealing that the risk instruments for fruit production are essentially subject to on-farm risk management tools (Deunick et al., 2008). From output price risk perspective, on-farm risk management instruments comprise marketing channels diversification (Mencarelli-Hofmann, 2009), proper fruit storage (Hirschauer and Mußhoff, 2012), prolongation of the fruitage period (Dierend et al., 2009) and products vending via reputable producer organizations (Steinborn and Bokelmann, 2007)

In the below figure 1, political risk is perceived by the farmers to be highest following the marketing risk. Political risk should not be underestimated, it is influencing various aspects of farmers' performances throughout the nation and globe, especially in a landlocked developing country, such as Afghanistan. Political 
risk is mainly arising from the unsteadiness in government structures, strategies and policies; another related category with political risk is a sovereign risk, which takes place due to the not commitment of the foreign government to the mutual agreements on trading issues (Hardaker et al., 2004), such instance of transaction risk is occurring due to the opportunistic behavior of transacting partners and highly reliability on them (Dorward et al.,2007).

Agriculture is inherently risky, because a wide range of exogenous factors is affecting the vast farming area, the majority of such environmental factors are out of human control. Thereby, farmers perceived environmental risk as a cause of uncertainty in the study area. Considering the high degree of fluctuation associated with environmental phenomena adaptation to climate change is the environment-friendly option for the farmers to combat risk and decrease the vulnerability rate inversely impacting farmers' output potential (Bradshaw et al., 2004). Such instance of environmental adaptation strategies includes but not limited to: diversification of crop varieties, planting in different points of time, proper irrigation, trees planting (Deressa et al. 2009; Bryan et al., 2009); soil conservation (Di Falco et al., 2011) and crop and livestock management practices (Nhemachena and Hassan ,2007). Moreover, Bryan et al. (2009), and Nhemachena and Hassan (2007) argued that firstly climate changes ought to be perceived by farmers, then chose appropriate individual adaptation strategies, purposively. Furthermore, the key determinants of the adaptation are identified including access to credit, markets, Information on climate change, access to fertile land, access to electricity and technology, and extension services Bryan et al. (2009); Nhemachena and Hassan (2007); Di Falco et al. (2011); Deressa et al., (2009). Moreover, risk arisen from exchange rates technically termed as currency risk are perceived to be very high in the study area; in addition, (Hardaker et al., 2004) argued that unpredictable exchange rates lead to currency risk.

Result of the multinomial logit model is shown in Table 7, documenting the effects of socioeconomic variables on farmers' preferences. Risk-coping strategies assessed in the study include intercropping, off-farm employment, decrease in expenditures, participation in cooperative unions, post-harvest management, financial/credit reserve and no-coping strategy (reference or base category), these all are assessed based on the given socioeconomic characteristics of farmers.

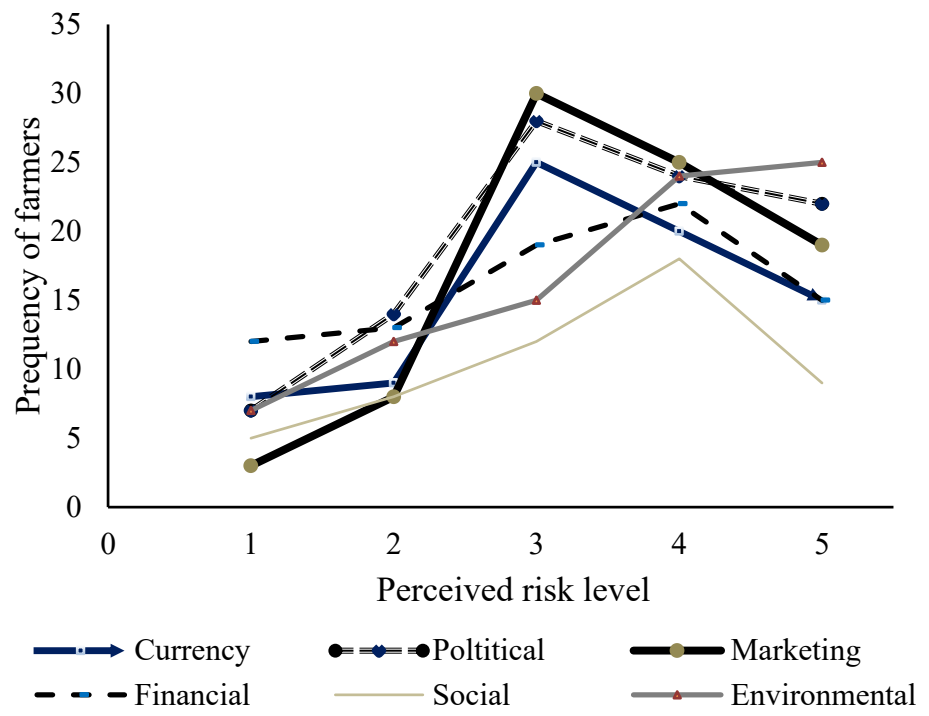

Figure 1: Farmers perception on risk sources along with apples production in the study area ( $1=$ very low, $5=$ very high) Source: Author's composition from the field survey, 2020

According to the likelihood ratio, the $\chi 2$ statistics (1403.45) is highly significant at $1 \%$ alpha level, indicating that the socioeconomic variables has a joint impact on farmers coping strategies for effective risk management in the study area.

The finding is consistent with the prior sign expectation of this study, revealing that garden size is positive and significantly related to the selection of various risk-coping strategies. Pointing out, that larger farm size has easiness and other incentives for various types of technology adoption, which assist farmers in the selection of numerous strategies to combat risk. Besides, the age of the farming household head was directly related to risk-coping strategies; implying that older farmers are more likely, skillful, and capable in risk management. The result is consistent with the empirical findings of studies arrived by Esiobu et al., (2014), and Kwesi and de-grafts Acquah (2012) stating that most of the farmers in the age of 41 to 50 years have more probability to accept innovations, because they are technically efficient, and could bear the risk involved in the production process. 
Table 4: Result of the Multinomial logit model on farmer risk-coping strategies and socioeconomic variables

\begin{tabular}{|c|c|c|c|c|c|c|c|c|c|c|c|c|}
\hline \multirow[t]{2}{*}{$\begin{array}{c}\text { Dependent } \\
\text { variable }\end{array}$} & \multicolumn{2}{|c|}{ Intercropping } & \multicolumn{2}{|c|}{$\begin{array}{c}\text { Off-farm } \\
\text { employment }\end{array}$} & \multicolumn{2}{|c|}{$\begin{array}{l}\text { Decreasing in } \\
\text { expenditures }\end{array}$} & \multicolumn{2}{|c|}{$\begin{array}{c}\text { Membership in } \\
\text { unions } \\
\text { (production/ } \\
\text { business) }\end{array}$} & \multicolumn{2}{|c|}{$\begin{array}{l}\text { Post-harvest } \\
\text { management }\end{array}$} & \multicolumn{2}{|c|}{$\begin{array}{c}\text { financial/credit } \\
\text { reserve }\end{array}$} \\
\hline & Coeff. & Wald & Coeff. & Wald & Coeff. & Wald & Coeff. & Wald & Coeff. & Wald & Coeff. & Wald \\
\hline Production & $34.30 * *$ & 15.11 & $-20.7 * *$ & 10.43 & $8.0 * * *$ & 22.45 & $15.2 * * *$ & 12.03 & $16.12 * *$ & 8.2 & 12.87 & 0.7 \\
\hline Garden size & 15.12 & 0.23 & $19.12 * *$ & 12.85 & $18.5 * * *$ & 11.1 & $3.23 * *$ & 6.12 & 20.35 & 1.62 & $17.45^{*}$ & 2.23 \\
\hline Age & $15.73 * *$ & 20.10 & $15.73 * *$ & 20.1 & $15.73 * *$ & 20.1 & $25.2 * *$ & 15.25 & $40.12 * *$ & 5.25 & 23.12 & 1.12 \\
\hline Education level & $15.76 * *$ & 12.13 & 3.34 & 0.73 & $34.3 * * *$ & 13.11 & 4.6 & 0.4 & $-7.13 * *$ & 24.52 & 38.12 & 1 \\
\hline Experience (year) & -13.34 & 17.20 & $18.46^{* *}$ & 14.52 & 8.23 & 2.55 & 11.15 & 1.62 & 50.23 & 0.6 & 22.42 & 0.45 \\
\hline Membership coop. & 25.3 & 1.92 & $15.73 * *$ & 20.1 & $35.45 * *$ & 6.01 & $23.24 * *$ & 5.53 & $33.97 * *$ & 1.23 & 5.2 & 0.26 \\
\hline Gender & 15.67 & 0.62 & $28.2 * * *$ & 4.15 & $-24.12 * *$ & 14.15 & $25.1 * *$ & 8.4 & $18.12 * * *$ & 27.12 & $29.43 * *$ & 4.22 \\
\hline Marital status & $-10.23 * *$ & 24.11 & 16.1 & 2.11 & $18.20^{* * *}$ & 15.25 & $15.7 * *$ & 20.1 & 15.24 & 9.21 & $25.43 * *$ & 12.32 \\
\hline Risk experience & $13.02 * *$ & 3.43 & 38.12 & 2.13 & 20.76 & 0.43 & 30.3 & 23.13 & $20.23 * *$ & 6.45 & $15.73 * *$ & 20.1 \\
\hline Household size & 12.53 & 2.25 & $70.23 * *$ & 35.21 & 33.23 & 1.61 & 40.12 & 0.55 & $35.12 * * *$ & 18.11 & $-33.35^{*}$ & 8.4 \\
\hline Off-farm income & $32.15 * *$ & 5.00 & 5.25 & 0.5 & 25.002 & 2.02 & $17.1 * *$ & 13.03 & $20.14 * *$ & 11.75 & $14.7 * * *$ & 11.63 \\
\hline Access to credit & 2.52 & 45.00 & 23.5 & 0.55 & 7.23 & 2.15 & 16.012 & 0.701 & $4.01 * *$ & 5.87 & 19.84 & 8.12 \\
\hline Extension agent & $17.1 * * *$ & 13.20 & $-27.0 * *$ & 17.05 & 5.06 & 0.6 & $17.2 * * *$ & 13.42 & 13.14 & 3 & $26.01 * *$ & 14.15 \\
\hline \multicolumn{13}{|c|}{ Reference Category: No-risk coping strategy } \\
\hline \multicolumn{13}{|c|}{ Likelihood Ratio Chi Square $(\chi 2): 1403.45$} \\
\hline \multicolumn{13}{|c|}{ Pseudo R-Square: 79.064} \\
\hline Total Observat & 85 & & & & & & & & & & & \\
\hline
\end{tabular}

Source: Stata result from field survey, 2020

$*$ Statistically significant at $10 \%$; **statistically significant at 5\%; *** statistically significant at $1 \%$

Also, the study found Gender to be significantly related to farmers' risk-coping strategies. Implicating that male farmer are more likely to use various option for effective risk management; the finding is identically in line with that of (Onubuogu et al., 2014) arguing that greater proportion of male farmer are technical efficient and productive because male farmers have tendency to be more labor efficient. The make-up of Afghan dominant culture also gives an advantage to the male farmer compared to the female ones on open access for choosing various options to manage the risk more effectively. Result, elucidated that education level of the household head had positive and significant impact on farmers' risk-coping strategies. Educated farmer has stronger capability in comparison to that of the uneducated farmers in effective risk This publication is licensed under Creative Commons Attribution CC BY. http://dx.doi.org/10.29322/IJSRP.10.07.2020.p10364 management, and mitigating the negative effects of risk. The result contributed by the empirical findings of Onubuogu and Esiobu (2014), and Nto et al., (2011) stating that educated farmer are more informative in adopting technology and increasing farm yield.

Farming experience and experience with risk had positive relationship along with all the risk-coping strategies. The result is in line with the finding of Nto et al., (2014), that expert farmers are more likely to hand-picked various risk coping strategies for effective risk management. Our study result revealed that access to credit and extension work was positive and significantly related to choosing the risk-coping strategies for handling and securing financial returns to the farm. 


\section{CONCLUSION}

In this study, we used risk behavioral model, and logistic regression analysis to examine the apple grower preferences toward risk and its determinants on a district level. The study revealed that majority of farmers in the study area are risk-averse and most of the farmers have severely experienced risk in the apple production. Moreover, result of the regression analysis found that production, age, education level, experience in farming, experience with risk, off-farm income and access to extension services are the main determinants of farmers' risk attitudes. Also, marketing, political, environmental and currency exchange risks are the main sources of risk from farmers' perspectives. The result of multinomial logit model, showed that the strategies used to combat the negative effects of risk include intercropping, off-farm employment, decrease in expenditures, participation in cooperative union, post-harvest management, and financial reserve. Risk and uncertainty in the apples production is highly associated with limited access to fair inputs and outputs markets, complicated and expensive financial services, inadequate access to valid information sources, and limited access to extension work. Therefore, the study has policy implications, it can be humbly suggested to the ministry of agriculture, irrigation and livestock on subsidizing farmers to improve their participation in the national and regional markets; furthermore, enhancement in the financial, information and extension services can assist farmers to lessen the negative effects of risk on the expected output; eventually it all could lead to proper implementation of the rural development programs and livelihood prosperity of farming families.

\section{REFERENCES}

[1] Adejoro, S.O., (2000). Handbook for Poultry Practitioners and Consultants. Jilog Nigeria Company, Ibadan

[2] Adubi, A.A. (1998). Conceptualizing the Economic Behaviour of Nigeria Small-scale Farmers: An Empirical Test of Two Hypotheses. Nigerian Journal of Economic and Social Studies, Vol. 40 (2), 171-181.

[3] Akcaoz, H., \& Ozkan, B. (2005). Determining Risk Sources and Strategies Among Farmers of Contrasting Risk Awareness: A Case Study for Cukurova region of Turkey. Journal of Arid Environments, Vol. 62 (4), 661-675.

[4] Apantaku, S.O., A.M. Omotayo, and A.B. Oyesola (1998). Poultry Farmers' Willingness to Participate in Nigerian Agricultural Insurance Scheme in Ogun State, Nigeria. (Editors: Oduguwa O O, Fanimo A O and Osinowo O A) Proceedings of the Silver Anniversary Conference, Nigerian Society for Animal Production. Gateway Hotel, Abeokuta. 2126 March 1998, 542.

[5] Aye G. O., Oji K. O. (2007). Effect of Poverty on Risk Attitudes of Farmers in Benue State, Nigeria $12^{\text {th }}$ Annual Conference on economic modeling for Africa. 4th-6th July, Cape Town, SA.

[6] Ayinde, O.E., O.A. Omotesho and M.O. Adewumi (2008). Risk Attitudes and Management Strategies of Small -Scale Crop Producer

in Kwara State, Nigeria: A ranking approach. African Journal of Business Management, Vol. 2 (12), 217-221.
[7] Babalola, D. A and Y. Babalola (2013). Economic Effects of Media Campaign against Pandemic Diseases: The Case of Bird Flu (H5N1) on Poultry Business in Ogun State, Nigeria. Arabian Journal of Business and Management Review, Vol. 2 (12), 80-88.

[8] Binswanger-Mkhize, H. P. (2012). Is There Too Much Hype About Index-Based Agricultural Insurance? The Journal of Development Studies, Vol. 48 (2), 187-200.

[9] Bradshaw, B., et al., (2004). Farm-Level Adaptation to Climate Change Variability and Change: Crop Diversification in The Canadian Prairies. Climatic Change, Vol. 67, 119-141.

[10] Bryan, E., Deressa, T., Gbetibouo, G. and Ringler, C. (2009). Adaptation to Climate Change in Ethiopia and South Africa: Options and Constraints. Journal of Environmental Science \& Policy, Vol. 12 (4), 413-426.

[11] Byrnes, J. P., D. C. Miller and W. D. Schafer (1999). Gender Differences in Risk Taking: A Meta-Analysis. Psychological Bulletin, Vol. 125 (3), 367-383.

[12] Chavas, J., and M. T. Holt., (1996). "Economic Behavior under Uncertainty: A Joint Analysis of Risk Preferences and Technology." The Review of Economics and Statistics, Vol. 78 (2), 329-335

[13] Chikaire J., Nnadi F. N., Ejiogu-Okereke N. (2011). The Importance of Improve Extension Linkages in Sustainable Livestock Production in Sub-Saharan Africa. Continental Journal of Animal and Veterinary Research, Vol. 3(2), 7-15

[14] Dadzie, S. K. Ndzebah and Acquah, H. de-Graft (2012). Attitudes Toward Risk and Coping Responses: The Case of Food Crop Farmers at Agona Duakwa in Agona East District of Ghana. Int'l J. of Agriculture and Forestry, Vol. 2(2), 29-37. 
[15] Dercon, S (2002). "Income Risk; Coping Strategies and Safety Nets" The World Bank Research Observer, Vol. 17(2), 141-166.

[16] Deressa, T., Hassan, R., Ringler, C., Alemu, T. and Yesuf, M. (2009). Determinants of Farmers' Choice of Adaptation Methods to Climate Change In The Nile Basin Of Ethiopia. Global Environmental Change, Vol. 19, 248-255.

[17] Deunick, J., Carels, K., Bas, L., Van Gijseghem, D. (2008). Risk Management in Agriculture and Horticulture, With The Focus On Insurance.

URL: [http://lv.vlaanderen.be/nlapps/docs/default.asp?id=1756] (26.09.2013).

[18] Di Falco, S., Veronesi M., Yesuf, M. (2011). Does Adaptation to Climate Change Provide Food Security? A Micro-Perspective from Ethiopia. American Journal of Agricultural Economics, Vol. 93 (3), 829-846.

[19] Eekeren N, Maas A, Saatkamp H and Verschuur M (1995). Small scale poultry production in the tropics. Wageningen: Agromisa.

[20] Einav, L.; Finkelstein, A.; Pascu, I.; Cullen, M.R., (2012). How General Are Risk Preferences? Choices Under Uncertainty in Different Domains. Am. Econ. Rev., Vol, 102, 2606-2638.

[21] ELLIS, F. (2000): The Determinants of Rural Livelihood Diversification in Developing Countries. Journal of Agricultural Economics, Vol. 51 (2). 289-302.

[22] Ellis, F. (1998). Household Strategies and Rural Livelihood Diversification. Journal of Development Studies, Vol. 35(1), 1-38.

[23] Euphrasie B.H., Kouame Aka, Narcisse Komenan, (2012). Risk Preferences and Demand for Insurance Under Price Uncertainty: An Experimental Approach for Cocoa Farmers in Côte D'ivoire, (13).

[24] Famure, O. O (1988) Survey of empirical evidence on technical economics of large scale poultry production in Borno State, Nigeria. J. of Animal Production and Research, Vol. 8(1), $49-61$

[25] Farrin, K. M. and Miranda, M.J. (2013). Premium Benefits? A Heterogeneous Agent Model of Credit-Linked Index Insurance and Farm Technology Adoption. Selected Paper Prepared for Presentation at the AAEA \&CAES Joint Annual Meeting, Washington, DC, August 4-6, 2013.

[26] Fawole, O.P and O, Fasina, (2005). Factors Predisposing Farmers to Organic Fertilizer Use in Oyo State, Nigeria. Journal of Rural Economics and Development, Vol. 14(2), 81-91.

[27] Flaten, O., Lien, G., Koesling, M., Valle, P.S. and Ebbesvik, M. (2005). Comparing Risk Perceptions and Risk Management in Organic and Conventional Dairy Farming: Empirical Results from Norway. Livestock Production Science, Vol. 95 (1-2), 11-25.

[28] Foster, W.E. and G.C. Rauser, (1991). Farmer Behaviour Under Risk of Failure. Am. J. Agric. Econ., Vol. 73 (2), 276-288.
[29] Gebremedehin, B and M.S. Scott, (2003). Investment in Soil Conservation in Northern Ethiopia: The Role of Land Tenure Security and Public Programs. Agricultural Economics, Vol. 29, 69-84

[30] Giné, X., Townsend, R. and Vickery, J. (2008). Patterns of Rainfall Insurance Participation in Rural India. World Bank Economic Review, Vol. 22(3), 539-566.

[31] Hardaker, J., Huirne, R., Anderson, J. and G, Lien (2004). Coping with Risk in Agriculture. Cambridge: CABI.

[32] Hazell, P. and Norton, R. (1986). Mathematical Programming for Economic Analysis in Agriculture. Macmillan, New York.

[33] Iqbal, M. A., Ping, Q., Abid, M., Kazmi, S. M. M. \& Rizwan, M., (2016). Assessing Risk Perceptions and Attitude Among Cotton Farmers: A Case of Punjab Province, Pakistan. International Journal of Disaster Risk Reduction, Vol. 16, 68-74.

[34] Isiaka, B. T., (1998). Livestock Rearing Practices and Problems in Lagos. In Oduguwa O O, Fanimo A O and Osinowo O A (Editors) Proceedings of The Silver Anniversary Conference, Nigerian Society for Animal Production. Gateway Hotel, Abeokuta. 2126 March 1998. $223-225$

[35] Karlan, D., Osei, R.D., Osei-Akoto, I. And Udry, C. (2014) Agricultural Decisions After Relaxing Credit and Risk Constraints. The Quarterly Journal of Economics, Vol. 129(2), 597-652.

[36] Kisaka-Lwayo, M.; Obi, A., (2012). Risk Perceptions and Management Strategies by Smallholder Farmers in Kwazulu Natal Province, South Africa. Int. J. Agric. Manag., Vol. 1, 28-39.

[37] Kwesi, N.D.S and H. De-Graft Acquah (2012). Attitudes Toward Risk and Coping Responses: The Case of Food Crop Farmers at Agona Duakwa in Agona East District of Ghana. International Journal of Agriculture and Forestry, Vol. 2(2), 29-37.

[38] Lamb, R.L., (2003). Fertilizer Use, Risk, Off-Farm Labor Markets in The Semi-Arid Tropics of India. Amer. J. Of Agric. Economics, Vol. 85 (2), 325-361.

[39] Liu Elaine M., (2013). Time to Change What to Sow: Risk Preferences and Technology Adoption Decisions of Cotton Farmers in China. The Review of Economics and Statistics, Vol. 4:1386-1403

[40] Lybbert, Travs J., And David R. Just, (2007). Is Risk Aversion 'Really' Correlated with Wealth? How Estimated Probabilities Introduce Spurious Correlation. American Journal of Agricultural Economics, Vol. 89, 964-979

[41] Lucas, M.P. And Pabuayon, I. M., (2011). Risk Perceptions, Attitudes, And Influential Factors of Rainfed Lowland Rice Farmers in Ilocos Norte, Philippines. Asian Journal of Agriculture and Development, Vol. 8(2), 6177.

[42] Menapace L., Colson G., Raffaelli R., (2012). Risk Aversion, Subjective Beliefs and Farmer Risk Management Strategies. American Journal of Agricultural Economics, Vol. 95(2), 384-389. 
[43] Mencarelli Hofmann, D. (2009). Für Eine Nachhaltige Wirtschaftlichkeit Im Apfelanbau [For Sustainable Profitability in Apple Production]. Agrarforschung, Vol. 16 (3), 58-63.

[44] Mikhaylova LI., (2005). "Risk Management in International Agricultural Markets" IAMO-Forum, Agricultural and Food Markets in Central and Eastern Europe, Seminar Paper 16-18 June, Halle (Saale)

[45] Moscardi, E. And A. De Javry, (1977). Attitude Towards Risk Among Peasants: An Econometric Approach. Am. J. Agri. Eco., Vol. 5, 710716.

[46] Musser, W.; Patrick, G., (2002). How Much Does Risk Really Matter to Farmers? A Comprehensive Assessment of the Role of Risk In U.S.; Just, R.E., Pope, R.D., Eds.; Kluwer Academic Publisher: Norwell, MA, USA.

[47] Njavro M., (2009). "Risk Management in Agribusiness." Paper Presented at Zagreb School of Economics and Management, June 5.

[48] NIPC, (2006). Nigerian Investment Promotion Commission Newsletter- A Quarterly Publication, $6^{\text {th }}$ Edition, July- September

[49] Nhemachena, C., And Hassan, R. (2007). Micro-Level Analysis of Farmers' Adaptation to Climate Change in Southern Africa. Africa, Vol. 714(August), 2.

[50] Nto, P. O.O, J.A Mbanasor, C.P.O Nto and A.E Osuala (2014). Evaluation of Risk Management Practices in Rice Production in Abia State, Nigeria. Swiss Journal of Management \& Business Studies, Volume 1 (1), 1-10.

[51] Nto, P.O.O; J.A Mbanasor and J.C Nwaru, (2011). “Analysis of Risk Among Agribusiness Enterprises Investment in Abia State, Nigeria. Journal of Economic and International Finance, Vol. 3(3), 187-194.

[52] Ayinde O. E., (200). Effect of Socio-Economic Factors on Risk Behaviour of Farming Households: An Empirical Evidence of SmallScale Crop Producers in Kwara State. Nigeria. Agricultural Journal, Vol. 3 (6), 447-453.

[53] Onubuogu, G.C; N.S. Esiobu; C.S Nwosu and C.N Okereke, (2014).Resource Use Efficiency of Smallholder Cassava Farmers in Owerri Agricultural Zone, Imo State, Nigeria. Scholarly Journal of Agricultural Science, Vol. 7(8), 142-152.

[54] Peter, M. And Susan, S. (2014). Determinants of Adoption of Pond Fish Farming Innovations in Salamaua of Morobe Province in Papua New Guinea. South Pacific Studies, Vol. 35 (1): 22-36.

[55] Pender, S. (2001). Managing Incomplete Knowledge: Why Risk Management Is Not Sufficient. International Journal of Project Management, Vol. 19, 79-87.

[56] Reynaud A., Couture R. (2012). Stability of Risk Preference Measures: Results from A Feld Experiment On French Farmers. Theory Decision, Vol. 73(2), 203-221.

[57] Sadoulet, And Alain De Janvry (1995). Quantitative Development Policy Analysis. Baltimore: Johns Hopkins University Press.
[58] Salimonu, K. K and A.O. Falusi (2007). Risk Preferences and Resource Allocation Differentials of Food Crop Farmers in Osun State, Nigeria. Journal of Rural Economics and Development, Vol 16(1), 1-12

[59] Scandizzo PL, Dillon JL (1976). Peasant Agriculture and Risk Preference in North East Brazil: A Statistical Sampling Approach. Paper Presented at CIMMYT Risk Conference EL Batah, Mexico, 9th$15^{\text {th }}$ March

[60] Sekar, I. And Ramasamy, C. (2001). Risk and Resource Analysis of Rainfed Tanks in South India. Journal of Social and Economic Development, Vol. 3(2), 208-215

[61] Shahabuddin, Q., S. Mestelman, And D. Feeny, (1986). Peasant Behavior Toward Risk and Socioeconomic and Structural Characteristics of Farm Household in Bangladesh. Oxford Economic Papers, Vol. 38, 122-130.

[62] Sulewski, P., \& Kłoczko-Gajewska, A., (2014). Farmers' Risk Perception, Risk Aversion and Strategies to Cope with Production Risk: An Empirical Study from Poland. Studies in Agricultural Economics, Vol. 116(3), 140-147.

[63] Tonye, A., J.A. Ikpi and D. Adegeye, (1977). Poultry Industry in Nigeria. J. Rural Eco. Dev., Vol. 2(2).

[64] Ullah, R.; Shivakoti, G.P.; Ali, G., (2015). Factors Effecting Farmers' Risk Attitude and Risk Perceptions: The Case of Khyber Pakhtunkhwa. Pakistan. Int. J. Disaster Risk Reduction, Vol. 13, 151-157.

[65] Weber, E. U., A.-R. Blais, And N. E. Betz. (2002). A Domain-Specific Risk-Attitude Scale: Measuring Risk Perceptions and Risk Behaviors. Journal of Behavioral Decision Making, Vol. 15(4), 263-90.

[66] Yesuf M., (2007). Risk Aversion in Low Income Countries: Experimental Evidence from Ethiopia" International Food Policy Research Institute Discussion Paper, Environment and Production Technology Division.

\section{AUTHOR}

Mr. Najeebullah Ahmadzai, Assistant Professor, Department of Agricultural Economics, Agriculture Faculty, Paktia University, Paktia, Afghanistan, E-mail: qnajeebullah@ymail.com 